\title{
Chicherin on the delimitation of Turkestan: Native Bolsheviks versus Soviet foreign policy. Seven letters from the Russian archives on razmezhevanie
}

\section{Hasan Ali Karasar}

To cite this article: Hasan Ali Karasar (2002) Chicherin on the delimitation of Turkestan: Native Bolsheviks versus Soviet foreign policy. Seven letters from the Russian archives on razmezhevanie, Central Asian Survey, 21:2, 199-209, DOI: 10.1080/0263493022000010080

To link to this article: https://doi.org/10.1080/0263493022000010080

$$
\text { 曲 Published online: } 01 \text { Jul } 2010 .
$$

Submit your article to this journal $₫$

Џ Article views: 116

Citing articles: 1 View citing articles $₫$ 


\section{Chicherin on the delimitation of Turkestan: native Bolsheviks versus Soviet foreign policy. Seven letters from the Russian archives on razmezhevanie ${ }^{1}$}

HASAN ALI KARASAR

\section{Introduction}

This is a short commentary on seven letters written by Chicherin, ${ }^{2}$ the People's Commissar for Foreign Affairs of the USSR between 1923 and 1930, and a prominent Bolshevik figure. These letters were written to Stalin, Zinov'ev, Kamenev, Trotskiy, Molotov, Rudzutak, Politburo members and members of the Collegium of Peoples Commissariat for Foreign Affairs. They are found in Rossiiskii tsentr khraneniia $i$ izucheniia dokumentov noveishei istorii (RTsKhIDNI) (Russian Center for Preservation and Study of Records of Contemporary History-Formerly the Central Party Archive), fond 17, opis 86, dela 24,1 . 13-20. There is no indication that they were published before, especially those concerning the discussions on National Territorial Delimitation policy. It is hoped that these will shed light on the standing of early Soviet foreign policy on the issue of delimitation and the positions of native Turkestani Bolsheviks.

Among scholarly circles it has generally been thought that razmezhevanie had been carried out centrally by the Politburo against the resistance of Native Bolsheviks in Turkestan. ${ }^{3}$ However, these letters seem to suggest that further research might be needed to find out the exact positions of both Russian Bolshevik leaders and National Communists of Turkestan.

Before summarising the main arguments in Chicherin's letters, it is important to remember two things: The first one is the fact that these letters were written at a time when Basmachi resistance to the Bolshevik regime was still quite popular and strong. The second point is that the nationalist Turkestani leaders in exile were quite confused about the good and evil of delimitation at least until the end of the 1920s. ${ }^{4}$ 


\section{The letters}

The first letter is dated 5 April 1924 and was addressed to Stalin with copies sent to Politburo members and the members of NKID Collegium. It is about the question of redistribution of the Middle ${ }^{5}$ Asian Republics as it appeared on the agenda of the Politburo. Chicherin's interpretation of this redistribution was basically putting Bukhara, Khiva and Turkestan (ASSR) into a big cauldron and then dividing them according to nationalities, thus creating a series of new Republics. ${ }^{6}$ Chicherin had strongly argued that the project and its timing was quite wrong. He was of the opinion that in the eyes of Western and Muslim countries, the project would put the USSR into a very difficult position. According to him, it was almost certain that the Muslim countries would protest at the elimination of the two traditional and historical Muslim states, Bukhara and Khiva. ${ }^{7}$ However, such a protest never occurred. On the other hand, for him, Kirghiz were comfortable with the status quo and were not prepared to leave the 'best-deliciou s pieces' to the Uzbeks. ${ }^{8}$

The second letter is dated 16 May 1924 and was addressed to the Politburo Central Committee of the Russian Communist Party with copies sent to Politburo members and the members of NKID Collegium. It concerns the reemergence of the redistribution issue on the agenda and its probable impacts on relations with Afghanistan, Iran and Turkey. After the first letter, this issue was postponed to the next party congress. ${ }^{9}$ In a few months the news about delimitation had spread all over Muslim countries and caused chaos and anger. ${ }^{10}$ Chicherin continued to argue very strongly that such delimitation, ending Bukhara's independence - a very 'respectable, traditional' and famous Islamic country-would cause a great scandal in the Islamic world that in turn, could help the British to increase their control over the Afghan Amir and generate a negative attitude against the Soviets. ${ }^{11}$

The third letter is dated 22 May 1924 and addressed to Stalin with copies sent to Politburo members and the members of NKID Collegium. It concerns the technicalities of the project. He argues that the project was prepared in an unnecessarily hurried atmosphere resulting in inconsistencies and weaknesses. ${ }^{12}$ Apparently Fayzulla Khodzhaev was one of the most enthusiastic of the Bolsheviks for the implementation of delimitation, but even he confessed to Chicherin that this unconscious and speedy transformation contained the threat of imminent clashes among traditional classes in Turkestan. ${ }^{13}$

The fourth letter is dated 28 May 1924 and is addressed to the Politburo Central Committee of the Russian Communist Party with copies sent to Politburo members and the members of NKID Collegium. It is about the report by Comrade German on the weaknesses of the project and the ambitions of the Uzbek Commercial Bourgeoisie to create a cotton-rich Uzbekistan by getting rid of the poor areas. ${ }^{14}$ In this letter, Chicherin openly blames the Uzbek Commercial Bourgeois class for supporting this project for creating a huge and complete cotton-producing rich region simply by including wealthy zones and getting rid of the impoverished zones. ${ }^{15}$ For Chicherin, both the Kirghiz (Kazakh) and the 
Khorezmian Bolsheviks were against the delimitation. The only reason Turkmen leaders supported the project was their expectation to become the leaders of such a new state. ${ }^{16}$

On the same day, Chicherin sent a secret letter to Zinov'ev (fifth letter), on an attempt to clarify his argument about the Bukharan Commercial Bourgeoisie supporting the delimitation project for the sake of greater profits. ${ }^{17}$ In this fifth letter, Chicherin also pointed out that the destruction of Khiva and Bukhara would consistently damage the Soviets' position in the East. ${ }^{18}$

The sixth letter is dated 6 July 1924 and addressed to Stalin with copies sent to Politburo members and the members of NKID Collegium. It refers again to the evils of delimitation. In this letter, as one of his final attempts to stop delimitation, Chicherin tried to convince Stalin that such a delimitation would have a significant negative effect on the long term foreign relations with all Muslim countries, including Turkey. ${ }^{19}$ Here, Chicherin emphasizes that even Fayzulla Khodzhaev (according to him, he was the principal and most enthusiastic supporter of the project) had serious reservations about stability in the region after the delimitation.

The seventh letter, written months after Chicherin lost his battle against delimitation, is dated 30 October 1924 and addressed to Stalin with copies to Comrades Kamenev, Zinov'ev, Trotsky, Molotov and Rudzutak. It is about the Turkmen National Bureau's attempts to include Turkmen populated territories of Iran into the Soviet Union. He was strongly opposed to this move. In his letter, which was written in an unusually informal and open tone, Chicherin asked Stalin to use all his authority on the Turkmen comrades to prevent this from happening. ${ }^{20}$

\section{Conclusions}

In these seven letters Chicherin seems to have five main arguments about the delimitation issue.

1. There is a significant risk-potential of destroying the international prestige of the young Soviet State among Muslim countries, especially in Turkey, Afghanistan and Iran. Delimitation would have the potential to create an anti-Soviet atmosphere in Turkey. As for Afghanistan, the Soviets had promised to save Bukhara's independence in the previous agreements. Thus delimitation would definitely give the British the upper hand in Afghanistan. Iran, worried about greater Turkmenistan, would be seriously affected by the project, as it would contribute to Lord Curzon's plans for the disintegration of young Iran.

2. There is a risk of ethnic unrest stemming from the desires for increased land and wealth. Chicherin opposed the plan strongly because he was against the destruction of an historical-traditional status-quo, which could end up with a change in Kirghiz (Kazakh)-Uzbek balance in the region and with increased tribal struggle among the Turkmen. According to him, while native Bolshevik 
leaders would be eager about the creation of national states, the masses would suffer most.

3. According to Chicherin, Bolshevik leaders were being manipulated by the local Uzbek commercial bourgeoisie (which included cotton merchants, rich farmers-dikhans, etc), who wanted to create a cotton-rich wealth zone.

4. Fayzulla Khodzhaev, the principal supporter of the project, also had reservations about the risk of unrest among the Uzbek social classes as a protest at the destruction of Holy Bukhara. However, for Chicherin the main initiators of the project were the native national communists who expected greater political roles in the region.

5. Chicherin found the project weak both technically and economically. He made several references to the economic aspects of the project in order to support his political arguments. Related to this, he argued that the project was full of inconsistencies, the timing was not appropriate, and further research was needed on the subject.

In conclusion, the content of these seven letters found in the Soviet archives provide new insights on the Soviets' delimitation policy in Turkestan. According to the commonly held perception, the Centre was seen as the main initiator of delimitation policy in Turkestan. However, Chicherin's letters seem to suggest that, not the Centre as such, but the native Bolsheviks may have initiated and lobbied for the delimitation policy. Furthermore, a Central figure like Chicherin, except for his exaggeration of the power of Uzbek commercial bourgeoisie, tried his best to alter the delimitation policy in Turkestan.

\section{Notes and references}

1. National-Territorial Delimitation of Borders. It is also translated as demarcation.

2. Georgiy Vasil'evich Chicherin (1872-1936), born in an aristocratic family; graduated from Petersburg University; served in the Foreign Service of the Tsar until 1904 when he joined revolutionary movement; and emigrated to Germany in the same year. In 1905, he joined Russian Social Democratic Workers' Party's Menshevik wing in Germany and he had worked with French and British socialists until 1917, when he was arrested in Britain just after the Bolshevik revolution. He was exchanged with the British Ambassador in Russia Sir George Buchanan in early 1918 and in his way back to Moscow, joined the ranks of Russian Communist Party. At his arrival, he was appointed the deputy Peoples' Commissar for Foreign Affairs and attended the last phase of Brest-Litovsk peace talks. In May 1918, he was appointed as the Peoples' Commissar for Foreign Affairs of the RSFSR and served as the Peoples' Commissar for Foreign Affairs of the USSR between 1923 and 1930. He had an interesting sympathy for the East and signed the friendship and neutrality treaties with Turkey in 1925, with Iran in 1927. However, it is impossible to determine the degree of his personal influence on the shaping of Soviet Foreign Policy, given the almost limitless interference of the Politburo into the area of Foreign Relations.

3. For one of the latest and best examples of such an approach see M. Zhuraev, R. Nurullin and S. Kamalov, 'Urta Osiye Khalklarining Milliy-Khududiy Chegaralanishi: Maksad va Mohiyat. Uzbekiston SSRning Tashkil Topishi', Uzbekistonning Yangi Tarikhi-lkinchi Kitob-Uzbekiston Sovet Mustamlakachiligi Davrida (Toshkent: Shark Nashriyet-Matbaa Kontserni, 2000), pp 282-302

4. In one of the first émigré periodicals of nationalist Turkestani leaders Yeni Türkistan, published in Istanbul between 1927 and 1932 by Osman Hoca and Mecdeddin Ahmed, there was an apparent policy not to criticize the National Communist Turkestanis. Writing in 1927, Ahmed Zeki Velidi seemed to accept the results of delimitation and replaced the old names with the new ones. '... For Maveraünnehr, in accordance with the current division, we will use Uzbekistan, for the Governorship of Steppe; Kazagistan, for Zakaspi (Maverayı Bahr-1 Hazer) governorship; Turkmenistan ...'. See Ahmed Zeki Velidi, 'Türkistân İsmi, Hudûdu ve Müsahası Hakkında', Yeni Türkistan, Ekim-Kasım, 1927, No 5-6, p 36. 
5. This is the term as it appeared in the letters. The writer used the 'Middle (Srednyaya) Asia' term in his letters instead of more conventional term 'Central (Tsentralnaya) Asia'.

6. Letter from Chicherin to Stalin. 305/2s copies to Politburo members and the members of NKID Collegium. Dated 5 April 1924, Rossiiskii tsentr khraneniia i izucheniia dokumentov noveishei istorii (RTsKhIDNI) [Russian Centre for Preservation and Study of Records of Contemporary History], f. 17, op. 86, d. 24, 1. 13. However in the same letter we understand that in the early phases of delimitation there was a wish to preserve the independence of Bukhara and Khorezm, which Chicherin was skeptical about.

7. Same document. RTsKhIDNI, f. 17, op. 86, d. 24, 1. 13. Chicherin was also critical about the results of national delimitation within the union too. According to him the status quo of the borders was quite old and traditional in Middle Asia and the consequences of new regulations could not be calculated in advance. Chicherin also argues that it would even be difficult to consider the unity of the Uzbeks of Bukhara and Samarkand as they would attack each other for the hegemony. He continued by pointing out that clashes among the native Turkmen tribes have already begun.

8. Same document. RTsKhIDNI, f. 17 , op. 86, d. 24,1 . 14. In the last paragraph of his letter Chicherin underlines that it is in fact only the Bukharan and the Khorezmian authorities that are quite eager for national delimitation. Both being in the desperate need of financial help, expect to increase their revenues.

9. Letter from Chicherin to Politburo Central Committee of Russian Communist Party. 474/kh copies to Politburo Members and the Members of NKID Collegium. Dated 16 May 1924. RTsKhIDNI, f. 17, op. 86, d. $24,1.15$.

10. Same document. RTsKhIDNI, f. 17, op. 86, d. 24, 1. 15. Chicherin here argues that Turkish and Afghan embassies reacted, in addition to anger in Iran to Soviets' plans for Greater Turkmenistan. He also underlines the fact that the Soviet-Afghan treaty was a safeguard to the independence of Bukhara.

11. Same document. RTsKhIDNI, f. 17, op. 86, d. 24, 1. 15. In late May, Chicherin was still struggling for the postponement of the plans in order to secure healthy foreign relations with the Islamic countries as well as with Turkey.

12. Letter from Chicherin to Stalin. 514/i copies to Politburo members and the members of NKID Collegium. Dated 22 May 1924. RTsKhIDNI, f. 17, op. 86, d. 24, 1. 16. Having a series of interviews with the Middle Asian native Bolsheviks, Chicherin was rather worried about the future of conflicts like the Teke Turkmen argument for domination over Bukharan and Khivan Turkmens, Bukharan Uzbeks vs Samarkandi's, etc. Chicherin concludes that it was a dangerous 'Pandora box'.

13. Same document. RTsKhIDNI, f. 17, op. 86, d. 24, 1. 16 Here Chicherin underlines that Fayzulla Khodzhaev championed the cause of national delimitation in Middle Asia.

14. Letter from Chicherin to Politburo Central Committee of Russian Communist Party. 543/i copies to Politburo Members and the Members of NKID Collegium. Dated 28 May 1924. RTsKhIDNI, f. 17, op. 86, d. $24,1.17$.

15. Same document. RTsKhIDNI, f. 17, op. 86, d. 24, 1. 17a. Arguing that delimitation would provide this class with huge profits, he also says that 'But one of the initiators of the project, Comrade Fayzulla Khodzhaev himself confessed to me that anger might occur among the great masses in the cities if Bukhara was eliminated. I think the price to pay would be a great uprising and the lives of many Red Army soldiers who would have to crush the rebellion ....'

16. Same document. RTsKhIDNI, f. 17, op. 86, d. 24, 1. 17a. Chicherin here also argued that Turkmens in their own territory would be isolated from rich agricultural areas and starve.

17. Letter from Chicherin to Comrade Zinov'ev. 541/ch Dated 28 May 1924. RTsKhIDNI, f. 17, op. 86, d. 24, 1. 18. He ends his letter by saying that 'How come that in order to satisfy the appetites of the Uzbek Commercial Bourgeoisie we have to put at stakes the state interests of the USSR?'.

18. Same document. RTsKhIDNI, f. 17 , op. 86, d. 24, 1. 18.

19. Letter from Chicherin to Stalin. 597/i copies to Politburo members and the members of NKID Collegium. Dated 6 June 1924. RTsKhIDNI, f. 17, op. 86, d. 24, 1. 19. '... It is meaningless to create commissions for the improvement of relations with Turkey when we intend to make all Muslim states our enemies with one blow .... He continues to blame Fayzulla Khodzhaev for supporting delimitation.

20. Letter from Chicherin to Stalin. 1341/ChS. Copies to Comrades Kamenev Zinov'ev, Trotsky, Molotov and Rudzutak. Dated 30 October 1924. RTsKhIDNI, f. 17, op. 86, d. 24, 1. 20. Note also Chicherin's emphasis on the Turkmen claims of territory on Iran helping the British and the Curzon's plans. Eventually Chicherin found common ground with Turkmen Bolsheviks and solved this question at the beginning of November. See his letter to Politburo. Letter from Chicherin to Politburo and copies to Politburo members and the members of NKID Collegium and Comrades Atabayev and Shumyatskiy. 1351/ChS dated 2 November 1924. RTsKhIDNI, f. 17, op. 86, d, 24, 1. 21. Following these letters, in RTsKhIDNI, f. 17, op, 86 , d. $24,1.22-28$, there exists a seven page long, quite detailed anonymous report on Middle Asia and native Bolshevik's positions on delimitation issue addressed to Georgiy Vasil'evich [Chicherin]. The author hopes to prepare this document for publication in the near future. 
To Comrade STALIN.

Copies to the Politburo Members and the Members of NKID Collegium.

\section{Dear Comrade,}

I have learned that the question of the redrawing of the Middle Asian Republics' boundaries was brought to the agenda of the Politburo: It is supposed to put Bukhara, Khiva and Turkestan into a big cauldron and to divide them according to the nationalitie s principle thus creating new republics. Strangely, it is added that Bukhara and Khorezm are supposed to retain a noticeable independence. This last statement makes more than strange reading.

Taking into consideration our position in the international arena, I personally think that such a measure would be to the highest degree untimely. The fact that we intend to liquidate not only two independent states but also plan to eliminate all traces of these two states by merging them with parts of Turkestan and re-dividing them, would be understood everywhere. It would create negative reaction towards us in the Muslim world and in the West. Even from the point of view of internal affairs I perceive this measure as very risky. Moreover, the present partition of Middle Asia as well as the states existing there has long-standing tradition. To shake out and re-divide all these republics means that apart from the already known difficulties a lot of new yet unknown ones would arise. If we unite parts of Bukhara and Samarkand, it would result in the hegemony of either Bukharan Uzbeks over Samarkandi Uzbeks or vice versa; these two kin peoples who hate each other and have been separated by several boundaries throughout history will fight each other continuously and hamper the maintenance of stability. The same will happen between different Turkmen groups, who already are in conflict over local issues. The discontent of the Kirghiz should be added to this as they do not want the current situation in Middle Asia to change. Particularly they do not want to leave to the Uzbeks quite delicious lands, nor do they want to merge with Orenburg and leave the Kirghiz part of Middle Asia under Orenburg's authority. Bukhara and Khorezm obviously aspire to this re-shaping because of their desperate need for subsidies as they do not receive any at present. They hope that this shaking out and their inclusion into the composite parts of the USSR would lead to the granting of subsidies by Moscow. Without any doubt, this is not the path we should follow.

With Communist Greetings.

/CHICHERIN/

[RTsKhIDNI, f. 17, op. 86, d. 24, 1.13-14] 


\section{HIGHLY SECRET}

May 16, 1924

To Politburo Central Committee of Russian Communist Party

Copies to the Politburo Members and the Members of NKID Collegium

The question of the redrawing of the Middle Asian map and of the liquidation of several Middle Asian states was postponed until the party meeting, and will be raised again in the next few days. Other Eastern states are already informed about these plans and have expressed great concern. We know of these concerns among the Turkish and Afghan political representations. Our plans for the creation of Great Turkmenia have long ago been a reason for furious anger in Persia. The liquidation of independent Bukhara, one of the most honourable and popular traditional Muslim states, whose independence we promised to maintain in our agreement with Afghanistan, could without a doubt result in great wrath in the Muslim world and a strong movement against us. At this difficult moment in our relations with Afghanistan when the English have blackmailed the Amir with a rebellion and forced him to call Anglophiles to power, such a scandalous act in the eyes of the Muslim world as the liquidation of Bukhara and Khiva, could draw the Amir irrevocably into the arms of England which helped him against the rebels that it triggered into action itself. There is no doubt that this would also cause a great movement against us in Turkey.

I do not understand why we should bring ourselves such great international difficulties and hardship when all these measures could easily be delayed until a more favourable moment.

NARKOMINODEL

/CHICHERIN/

20 Copies

[RTsKhIDNI, f. 17, op. 86, d. 24, 1.15]

May 22, 1924

To Comrade STALIN

Copies to the Politburo Members and the Members of NKID Collegium

Dear Comrade,

It has been absolutely clear to me from the latest reports of Comrade Znamenskiy and my conversations with Middle Asian activists that the issue of national delimitation has not been thought out enough. A series of inconsistent solutions have been proposed and all of them have been formulated very thoughtlessly. The economic dimension of the issue has not been taken 
sufficiently into consideration and there may be unpleasant consequences if one moves unnecessarily quickly.

From the point of view of international politics it should definitely be postponed. The liquidation of Bukhara would be understood as the elimination of an independent Muslim State and could result in an out-cry against us. It would be a violation of the agreement we have made with Afghanistan regarding the independence of Bukhara. At the moment when the English have succeeded in infiltrating Afghanistan under the convenient pretext of a rebellion, it would be dangerous to give such a weapon into their hands.

The internal situation in the Middle Asian republics is a picture of war where everyone is against everyone, and this is the case with different nationalities. Everyone is carrying a stone that could be thrown at another in his breast and everyone has divided the skin of a not yet hunted bear. It is being discussed now whether Teke Turkmens are superior to Bukharan or Khivan Turkmens, or whether Bukhara is superior to Samarkand or Samarkand superior to Bukhara; all regions are getting involved in the controversy and the destiny of Tashkent is being discussed. This place is like a beehive, a Pandora's box. Antagonisms have already appeared around the unpleasant issue of national delimitation. The rapid and careless implementation of national delimitation may lead to a general and real conflict.

Even Faizulla Khojaev, a very enthusiastic supporter of national delimitation, confessed to me that the liquidation of traditional holy Bukhara may create a serious "fermentation" - unrest if not more, among the city-dweller middlebourgeois masses, small commercial classes and big dikhan-farmers. Obviously taking all this into account the planed changes are not well prepared.

With Communist Greetings.

/CHICHERIN/

[RTsKhIDNI, f. 17, op. 86, d. 24, 1. 16]

COMPLETELY SECRET

May 28, 1924

To the Politburo Central Committee of Russian Communist Party.

Copies to the Politburo Members and the Members of NKID Collegium.

The report of Comrade German that I received shows that our best Middle Asian workers have very negative or hesitant views of the so-called project on delimitation of Middle Asia. Comrade German highlights the dangers related to the project and the fact that it has been weakly developed.

Indeed, we could say that this project is not elaborated at all. Conflicts have already started among many nationalities over the regions concerned. All the contentious points of debate remain unsolved and have not been addressed. It is 
already clear that the implementation of this plan would bring great disagreements in Middle Asia.

Comrade German agrees that at the moment we should stay away from hurried and ill-thought decisions, especially those that may affect the USSR's international position. Verily, everybody in the Muslim world would interpret the liquidation of the ancient Muslim states of Bukhara and Khiva as a blow to Islam and to Eastern peoples. Such a situation would seriously endanger our international position in the East; it would bring great damages and create serious problems for us. And what for?

It is becoming clear that the main initiators of the national delimitation - the Uzbek commercial bourgeois - hope to get rid of poor areas and create a large cotton-producing region, which would provide them with commercial opportunities. But one of the initiators of the project, Comrade Faizulla Khojaev himself, confessed to me that anger might occur among the great masses in the cities if Bukhara is liquidated. I think that the price to pay would be a great uprising and the lives of many Red Army soldiers who would have to crush the rebellion.

Turkmen political figures are supporting the project because it would give them an opportunity to become heads of the new state. But the Turkmen masses would suffer if their poor lands are separated from better-off Uzbek regions, and they would die in misery.

Khorezmian political figures are totally against delimitation because Khorezm is located behind the deserts. It is in fact absurd to divide it into pieces and unite it with other regions. Kirghiz people are absolutely against delimitation.

To go ahead for the sake of the Uzbek commercial bourgeois' beautiful eyes would not be an expedient policy, especially if it creates serious problems for the USSR.

NARKOMINODEL

/CHICHERIN/

[RTsKhIDNI, f. 17 , op. 86 , d. 24, 1. 17-17 obr.]

HIGHLY SECRET

May 28, 1924

\section{To Comrade ZINOV'EV.}

Dear Comrade,

As you are particularly close to international politics, I would like to draw your attention to the immense threat that we may be faced with as a result of the national delimitation in Middle Asia. Eastern ambassadors in Moscow are already concerned about this matter. Can you imagine what devastating impact 
the liquidation of such ancient Muslim states as Khiva and Bukhara would have on the Muslim world? This may seriously endanger our position in the East and create great difficulties for us. The Bukharan commercial bourgeois strive to realise national delimitation because of the benefits it would bring to the cotton merchants. But in the same Bukhara, the elimination of the ancient state may cause serious unrest amongst the city's small bourgeois and rich peasants. As a result we may be faced with a serious revolt. How come that in order to satisfy the appetites of the Uzbek commercial bourgeoisie we have to put at stake the state interests of the USSR?

With Communist Greetings.

\section{/CHICHERIN/}

[RTsKhIDNI, f. 17, op. 86, d. 24, 1. 18]

June 6,1924

To Comrade STALIN.

Copies to the Politburo Members and the Members of NKID Collegium

Dear Comrade,

In his latest report Comrade German once again indicates that the question of the so-called national delimitation in Middle Asia is still not fully elaborated and that its economic side was left without review.

What interests me most as NKID is that national delimitation will radically spoil our relations with Muslim states for a long time. It is meaningless to create commissions for the improvement of relations with Turkey when we intend to make all Muslim states our enemies in one blow.

Moreover, added to these diplomatic concerns, all discussions regarding this topic convinced me utterly that the question has not been thought out. A Pandora's box is being created, where all will be fighting against all.

One of the leading supporters of national delimitation, Faizulla Khojaev, has confessed to me that small bourgeois city masses will be deeply concerned about the liquidation of "Holy Bukhara". Undoubtedly we are going towards a serious rebellion. How come we allow this?

From the point of view of economic relations the project of national delimitation would create something absolutely unreal. Middle Asia, which has already suffered a lot, is thus going toward serious disaster.

It is absolutely clear that this project needs long and careful elaboration before any measures can be taken.

With Communist Greetings.

/Chicherin/

\section{Copies}

[RTsKhIDNI, f. 17, op. 86, d. 24, 1.19]

No1341/ChS 
To Comrade STALIN.

Copies to Comrades Kamenev, Zinov'ev, Trotskiy, Molotov and Rudzutak.

Dear Comrade,

I am extremely concerned about an appeal sent to you by the Turkmen national bureau regarding Persian Turkmenia. This revives exactly Curzon's programme: to cut a piece from Persia and to repel the Persian national movement from the USSR. Our eastern policy strives to associate the USSR with all the Eastern states against imperialism. If instead we aim to incorporate parts of the Eastern states to the USSR, it would turn our eastern policy upside down and would make our previous goals unattainable. An attempt by Soviet Turkmens to seize a part of Persia inhabited by Turkmens, would result in our breaking up with the Persian national movement. This would be paramount to a political defeat. I urge you to use your influence on the Turkmen comrades in order to dissuade them from seizing the Turkmen parts of Persia. A proposal to give Persia territorial compensation for the annexation of these parts to the USSR is an empty phrase, because there exist no such compensations.

With Communist Greetings.

/CHICHERIN/

[RTsKhIDNI, f. 17 , op. 86, d. 24, 1. 20] 